\title{
Positioning Strategic Sustainable Facilities Management (SFM) for Hotel Industry in Malaysia
}

\author{
Alyaa Afifah Abu Talib 1, Nor Rima Muhamad Ariff ${ }^{1}$, \\ Mohamad Sufian Hasim ${ }^{1}$, Mohd Hafiz Hanafiah ${ }^{2}$ \\ ${ }^{1}$ Centre of Studies for Postgraduate, Faculty of Architecture Planning and Surveying, \\ 2 Faculty of Hotel and Tourism Management, \\ Universiti Teknologi MARA, Shah Alam, Selangor, Malaysia \\ alyaaafifa@gmail.com,norri550@uitm.edu.my,moham315@uitm.edu.my, hafizhanafiah@uitm.edu.my
}

\begin{abstract}
Sustainability issues in the hotel industry are significantly distressing matter. It has been expressed as a constituent interest to a negative impact on the environment. However, the sustainability management concept is yet to be established by the Malaysian hotel industry. The aim is to study Sustainable Facilities Management (SFM) practices in the hotel industry. This conceptual paper encompasses on evolution theory of SFM. Meta-analysis was conducted focusing on developing trends of SFM globally. The findings revealed that 9 out of 15 sustainable initiatives have been commonly practised. These initiatives are essential to gain holistic SFM practices in the hotel industry.

Keywords: Sustainable; Sustainability Facilities Management (SFM); Hotel.

2398-4279 @ 2019 The Authors. Published for AMER ABRA CE-Bs by E-International Publishing House, Ltd., UK. This is an open-access article under the CC BY-NC-ND license (http://creativecommons. org/licenses/by-nc-nd/4.0/). Peer-review under responsibility of AMER (Association of Malaysian Environment-Behaviour Researchers), ABRA (Association of Behavioural Researchers on Asians) and cE-Bs (Centre for Environment-Behaviour Studies), Faculty of Architecture, Planning \& Surveying, Universiti Teknologi MARA, Malaysia.

DOI: https://doi.org/10.21834/ajqol.v4i17.200
\end{abstract}




\subsection{Introduction}

Malaysia has reaffirmed with the United Nations Sustainable Development Summit to support and commitment to implement the 2030 Agenda for Sustainable Development and its 17 Sustainable Development Goals (17SDGs). In aligning with Malaysia National Ecotourism Plan (MNEP) (2016): Chapter 1- Strategic 3, Action 4 agenda, the hotel industry is urged to adhere to the sustainability principles and practices in the existing hotels. The persistence is to support the 17 SDGs global goal since the sustainability issues in the hotel industry are now increasingly known as a significant concern (United Nations World Tourism Organization (UNWTO), 2018). A wide recognition across the globe by many organization on the sustainability practices was shown from plenty of evidence (Hasim et al., 2012). Although the studies on sustainability concern had been well researched in various settings (AlonsoAlmeida, Fernández Robin, Celemín Pedroche, \& Astorga, 2017; Bohdanowicz, 2005; Nielsen, Sarasoja, \& Galamba, 2016), there is still lack of evidence from the hotel industry.

In terms of sustainability, the hotel industry's sustainability concept had begun to gain momentum in this industry recently (Ernst and Young, 2013). Globally, accommodation (e.g. hotel, motel, holiday apartments, camping ground) is responsible for an estimated $21 \%$ of pollutions and emissions from tourism (United Nation Environmental Protection (UNEP), 2017; United Nations Environment Program (UNEP), 2008). Thus, many hotel organizations have considered implementing sustainable initiatives practice such as, reducing waste, energy and water consumption, in which they agreed these practices resulted in a positive impact to the environment while it offers economic benefits in return (UNEP, 2008). Besides, UNEP (2008) reported that hotel environmental management programs could also have significant repercussions for positive stakeholder's perceptions.

Previous studies had reported that sustainability facilities management had become a necessary practice to adopt in hotel industry these days to maintain their competitive position (Alonso-Almeida et al., 2017; Bruns-smith et al., 2015; International Facility Management Association (IFMA), 2018; Jenkins et al., 2014; Junghans et al., 2014; Nielsen et al., 2016). Besides, International Facility Management Association(IFMA) reported, natural resources have depleted, which pushing Facility Management (FM) professionals to develop competencies in areas of sustainable development and practices within their organizations (IFMA, 2018). Based on the literature, there seems to be a full recognition of the benefits and importance of incorporating sustainability into FM practice (Alonso-Almeida et al., 2017; Baaki et al., 2016; Elmualim et al., 2012; Elmualim et al., 2009; Jenkins \& Karanikola, 2014; Nielsen et al., 2016) however, studies and literature focusing on the drivers of SFM are very few, particularly in hotel industry. Hence, the study is to focus on the Sustainable Facilities Management (SFM) practices within the hotel industry. The focus of this paper is to identify the key initiatives of SFM implemented for the hotel industry in Malaysia.

\subsection{Facilities Management (FM)}

Facilities Management (FM) has evolved from property to the construction industry as well as recognized in other sector industries. Presently, FM has acknowledged as the fastest 
emerging and most important sector in many industries, having gained recognition from the 1970s when outsourcing services became popular in radical cost-cutting initiatives (Alexander, 2009). Since then, in the late 80 s and early 90 s, it has been witnessed as rapid development growth (Meng, 2015). FM is well known for its emerging, multi-disciplinary professions that cover a variety of services from core to non-core function of delivering the strategic decision-making process. Besides typically seen in the operational sense of cleaning, care-taking, repairs and maintenance, FM now covers "real estate management, financial management, change management, human resources management, health and safety, contract management, in additional to building and engineering services maintenance, domestic services and utilities supplies" (Alexander, 2009; International Facility Management Association (IFMA), 2018). A chronology of how FM has transformed is provided by (Alexander, 2009) as per Table 1.

Table 1: Evolution of FM

\begin{tabular}{cclc}
\hline Period & Generation & \multicolumn{1}{c}{ Activity } & Level \\
\hline $1970 \mathrm{~s}$ & $1^{\text {st }}$ & $\begin{array}{l}\text { Managed services, outsourcing, total facilities management, } \\
\text { CAFM }\end{array}$ & Operational \\
\hline $1980 \mathrm{~s}$ & $2^{\text {nd }}$ & $\begin{array}{l}\text { Quality management, management agency, benchmarking, } \\
\text { FM process, FMIS }\end{array}$ & Tactical \\
\hline $1990 \mathrm{~s}$ & $3^{\text {rd }}$ & $\begin{array}{l}\text { Partnering, re-engineering processes, knowledge } \\
\text { management, product innovation, Sustainable Facilities } \\
\text { Management (SFM) }\end{array}$ & Strategic \\
\hline
\end{tabular}

(sources: Alexander, 2009)

Today, sustainability adaptation into FM practice is not an odd context, yet it supports to deliver more effective and competent strategic in business organizations. As highlighted by Nielsen \& Galamba (2010), the implementation of sustainability in FM practice is significant in the strategic response of any business entity. Nonetheless, the process of integrating sustainability into FM practices is not the same for all organizations. The integration is unique for the specific type of business as they differ in terms of facility features, organizational scale, business sector, organization characteristics, the context of operation and culture (Chotipanich, 2006). For instance, the FM needs to comply in diverse types such as; residential, educational, institutional, industrial, hospitality and vary in terms of the building engineering system, ownership, scale, location and building type (Nazeer, Gunatilake, \& Ramachandra, 2019). According to Hodges (2014), the notion of sustainability discipline of FM competency in the strategic level was recognized since the 1990s (Table 1). Notably, the integration of sustainability stewardship competency in FM areas propensities into environment-behaviour and it is significantly the top core competencies for facility managers in managing either built and natural environments. Hodges (2014) added, sustainability in FM is holistically deliberate and strategically mature in sustaining for the environmentbehaviour, which generate high-performance standard (Table 2). 
Table 2: Holistic proficiency of SFM

\begin{tabular}{cl}
\hline Organization Level & \multicolumn{1}{c}{ Roles of SFM in Organization } \\
\hline Strategic Level & $\begin{array}{l}\text { Establish vision and demonstrate policy in responsibility for long term direction, goal } \\
\text { setting and decision making }\end{array}$ \\
\hline Tactical Level & Communicate the policy of SFM strategy and continuous improvements initiatives \\
\hline Operational Level & Execute day-to-day management and participate in performance development \\
\hline
\end{tabular}

(sources: Hodges, 2014)

Additionally, the nature of sustainability practices varies; whether reducing energy usage, improving energy efficiency, increasing the use of renewable energy, carbon offsetting strategies, sustainable destination planning and management, as well as other changes in business practices (United Nations Environment Program (UNEP), 2008). Hence, sustainable practice is a significantly important area in FM professionals, in which they need to develop their competencies to face the future demands, challenges and opportunities of sustainable development and practices (British Institute of Facilities Management (BIFM), 2018).

\subsection{Sustainable Facilities Management (SFM)}

According to International Facility Management Association (IFMA) (2018), defined Sustainable Facilities Management (SFM) as a process of integrating the people, place, and business of an organization in a way that optimizes economic, environmental and social benefits of sustainability. In other words, SFM extrapolated as the delivery of sustainability stewardship within the FM context. The IFMA emphasized the need for facilities managers to retain the ability to make a "business case for sustainability" and develop sustainability initiatives practices. Similarly, identified integrating all sustainability considerations, linking strategic level with operational level, incorporating FM knowledge and experience into the design, disseminating sustainable knowledge and educating people, encouraging sustainability through innovation as crucial roles facilities managers could play in sustainable FM practice (IFMA, 2018).

Sustainable development is now accepted as a critical success factor and a notion applicable to both governments and in any industry (Brundtland International Institute for Sustainable Development, 2017). Since then, the notion of sustainability development had been mentioned in various international platforms and, the movement towards "sustainability" had been expanded across the globe. The general idea of sustainable facilities management (SFM) is to incorporate sustainability practices into the operations and implementation of facilities management functions. In essence, SFM is not a new practice but instead merging practices of integrated principles concerning social, economic and environmental policies of sustainability into the existing notion of FM. As a logical conclusion, this highlights the need for more multi-disciplinary and trans-disciplinary research to support the emerging discipline of SFM in the hotel industry.

Today, SFM is well-acknowledged as a best practice employed by companies worldwide. The focus on sustainability helps organizations manage their social and environmental 
impacts and improve their operating efficiency and natural resource stewardship. The movement towards a greater emphasis on sustainability, world infrastructure, and technology received various incentives, momentum and occasionally obligation to adapt accordingly to its associated trends. Since then, Sustainable Facilities Management (SFM) has been identified as one of the emerging themes in the future of FM research has been one of the top research themes in EuroFM network (Junghans \& O.E. Olsson, 2014) and an increasing number of published research articles and discussions (Nielsen et al., 2016).

\subsection{SFM and the Hotel Industry}

Sustainability concern encompasses most industries (Iwanowski \& Rushmore, 1994) and people are becoming increasingly aware of the damage inflicted on the environment by business activities, changing consumers' behaviours and company operations(Jenkins \& Karanikola, 2014). The past several decades have seen a growing awareness amongst hoteliers regarding the environmental and social impacts of hotel development and operations on the extent where sustainability issues have permeated nearly every aspect in the hotel industry. The growing sustainability awareness had driven multiple factors, including owners' and operators' desires to reduce operational costs, changing investor attitudes toward the environment, the increased regulatory focus on facility operations and development, and a customer shift towards greener hotels (Goldstein \& Primlani, 2012). The roots of sustainability thought in the hotel industry became evident over half a century ago, when a few hoteliers realized they could provide an enhanced guest experience by integrating natural/green elements into the customers' staying experience (Goldstein \& Primlani, 2012).

Consequently, managing the facilities well helps to improve a hotel's efficiency and adds value to their performance and services (Penny, 2007). However, without proper integration of sustainability's hotel FM, the core businesses of hotels (e.g. guestrooms, food, and beverages) would be affected negatively (Durodola et al., 2012). It is important to note that the hotel industry generates a lot of adverse environmental impacts which are often associated with excessive consumption (UNEP, 2008) of local and imported non-durable goods, energy and water, followed by emissions released to air, water, and soil (Penny, 2007). Many researchers have report that improving hotel environmental performances would lead to the reduction of energy consumption and operational costs (Bruns-smith et al., 2015; Göğüş et al., 2013; Melissen et al., 2016), generate an environmentally friendly environment for both staff and customers and help raising the company's corporate image and gaining the competitive edge (Baaki et al., 2016; Jayawardena et al., 2013; Jenkins \& Karanikola, 2014; Nielsen et al., 2016; Zaiton et al., 2016). Accordingly, Baaki et al., (2016) and; Lai \& Choi, (2015) have highlighted the importance of adopting a holistic approach of sustainability, in which by assessing the SFM practice. Also, Baaki et al., (2016), stated that it is a necessity for determining the SFM initiatives to be implemented in the organizations. The SFM approach in the hotel organizations is vital that contemporary managers recognize the specificities enshrouded in economics, society, and environment by observing systemic 
issues within their organizational structure. Thus, it is crucial to create criteria capable of inducing modern management to employ SFM practices that entwined to ethical and responsible values specificities from any organization. The Association of Southeast Asian Nations (ASEAN) was established in 2016 as a guideline of 'ASEAN Green Hotel Standard' for hotel organizations to increase the Environmentally friendly and Energy Conservation in the ASEAN Accommodation industry, with a unified agreement across the ASEAN Members States (ASEAN Green Hotel Standard (AGHS), 2016). However, in Malaysia, the SFM practice within the hotel industry is still lacking and limited (Yusof \& Jamaludin, 2013; Zaiton et al., 2016). In particular, most of the hotel FM efforts should be channelled to improve organizational effectiveness and well-being by adopting the SFM approach in addressing the issues of environmental management in the hotel industry (Lai \& Choi, 2015).

\subsection{Methodology}

This study gathered and reviewed the SFM practice around the globe and was then merged with information before the literature on the particular initiatives that apply to the hotel industry. A qualitative approach was used in this study to gather the research data. The metaanalysis systematically analyzed available guidelines of sustainable practice for the hotel industry around the world (Table 2). The purpose of the meta-analysis is to review a variety of existing sources (e.g., documents, reports, data files, and other written artefacts) to collect independently verifiable data and information (Bowen, 2009; Neuman, 2014). Bowen (2009) also defined that meta-analysis is a systematic procedure for reviewing or evaluating documents, either both printed and electronic (computer-based and Internet-transmitted) material. Like other analytical methods in qualitative research, meta-analysis requires that data be examined and interpreted to elicit meaning, gain understanding, and develop empirical knowledge (Creswell, 2014; Neuman, 2014).

\subsection{Results}

Table 3 below shows a total of 15 initiatives were discover from the documents analyzed. There are ten countries and continents who published their strategic plans of SFM practice and guidelines for the hospitality sector. They are the United States of America (EPA, LEED, Green Globe, Green Seal), United Kingdom (Global Sustainable Tourism Council-GSTC), European countries (EMS), New Zealand (Green Globe), Australia (EarthCheck), Canada (Green Key Global), China (LEED), Japan (GSTC) and ASEAN countries (ASEAN Green Hotel Standard-AGHS). The strategic sustainable initiatives for the hotel industry are presented in Table 3.

Furthermore, this study found that the most significant and pertinent initiatives of SFM focus only on nine key initiatives that are most required and useful specifically for the hotel industry. The nine key initiatives identified were must are policy, human resource, green products, community collaboration, energy management, water management, waste management, air quality management and noise management (Table 4). Table 4 below 
shows a report on the SFM key initiatives that are most significant for the implementation in the hotel industry in Malaysia.

Table 3: Strategic sustainable initiatives for the hotel industry across the globe

\begin{tabular}{|c|c|c|c|c|c|c|c|c|c|c|}
\hline $\begin{array}{l}\text { Sustainable } \\
\text { Initiatives }\end{array}$ & ת & 号 & 昰 & 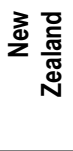 & 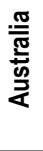 & 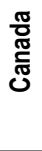 & 茎 & $\begin{array}{l}\text { 등 } \\
\text { 응 }\end{array}$ & $\begin{array}{l}\frac{0}{0} \\
\frac{0}{\square} \\
\frac{5}{5}\end{array}$ & 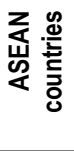 \\
\hline Policy Plan & - & - & - & - & $\bullet$ & - & - & - & - & - \\
\hline Human Resource & $\bullet$ & $\bullet$ & $\bullet$ & $\bullet$ & $\bullet$ & $\bullet$ & $\bullet$ & $\bullet$ & $\bullet$ & $\bullet$ \\
\hline Green Products & $\bullet$ & $\bullet$ & $\bullet$ & $\bullet$ & $\bullet$ & $\bullet$ & $\bullet$ & $\bullet$ & $\bullet$ & $\bullet$ \\
\hline Community Collaboration & $\bullet$ & $\bullet$ & $\bullet$ & $\bullet$ & $\bullet$ & $\bullet$ & $\bullet$ & $\bullet$ & $\bullet$ & $\bullet$ \\
\hline Energy Management & $\bullet$ & $\bullet$ & $\bullet$ & $\bullet$ & $\bullet$ & $\bullet$ & $\bullet$ & $\bullet$ & $\bullet$ & $\bullet$ \\
\hline Waste Management & $\bullet$ & $\bullet$ & $\bullet$ & $\bullet$ & - & - & - & - & - & - \\
\hline Water Management & $\bullet$ & $\bullet$ & $\bullet$ & $\bullet$ & $\bullet$ & $\bullet$ & $\bullet$ & $\bullet$ & $\bullet$ & $\bullet$ \\
\hline Air Quality Management & $\bullet$ & $\bullet$ & $\bullet$ & $\bullet$ & $\bullet$ & $\bullet$ & $\bullet$ & $\bullet$ & $\bullet$ & $\bullet$ \\
\hline Noise Management & $\bullet$ & $\bullet$ & $\bullet$ & $\bullet$ & $\bullet$ & $\bullet$ & $\bullet$ & $\bullet$ & $\bullet$ & $\bullet$ \\
\hline Green Growth & - & & & & & & & - & & \\
\hline Land & $\bullet$ & & & & & & & & & \\
\hline Marine \& Coast & $\bullet$ & & $\bullet$ & & $\bullet$ & & & $\bullet$ & $\bullet$ & \\
\hline Urban Environment & $\bullet$ & & & $\bullet$ & & $\bullet$ & & $\bullet$ & $\bullet$ & \\
\hline Nature \& Biodiversity & $\bullet$ & $\bullet$ & $\bullet$ & $\bullet$ & - & $\bullet$ & - & - & & \\
\hline Soil Management & $\bullet$ & & & $\bullet$ & & & & $\bullet$ & & \\
\hline
\end{tabular}

(Sources: Environmental Protection Agency (EPA)(2013); EMS (2008); Green Seal (2018); EarthCheck (2018); Green Globe (2014); Global Sustainable Tourism Council (GSTC) (2013); LEED (2013); Singapore Tourism Board (STB)(2015); Green Key Global (2010); ASEAN Green Hotel Standard (AGHS)(2016)).

Table 4: Nine (9) SFM key initiatives for the hotel industry

\begin{tabular}{|c|c|}
\hline SFM Initiatives & Literature \\
\hline $\begin{array}{l}\text { Policy plan } \\
\text { (Junghans, 2011; Londoño } \\
\text { \& Hernandez-Maskivker, } \\
\text { 2016; Nielsen et al., 2016) }\end{array}$ & $\begin{array}{l}\text { - Change corporate culture and strategizing policy towards sustainability. } \\
\text { - Adopt SFM as strategic management instruments to improve performance. }\end{array}$ \\
\hline $\begin{array}{l}\text { Human Resource (HR) } \\
\text { (Bohdanowicz, Zientara, \& } \\
\text { Novotna, 2011; Chan \& Hsu, } \\
\text { 2016; Fotiadis, Vassiliadis, \& } \\
\text { Rekleitis, 2013; Kutanis et al., } \\
\text { 2012; Razumova, Rey- } \\
\text { Maquieira, \& Lozano, 2016) }\end{array}$ & $\begin{array}{l}\text { - Manage the hotel's HR involving accurate strategic plans and goals as planned. } \\
\text { - HR as coordinator for business strategies to gain sustainable advantages. } \\
\text { - Participation from HR leads to long term sustainable practices and success. } \\
\text { - Top management patronage towards HR activities (i.e., sustainable training, } \\
\text { employee empowerment, teamwork and rewards systems) is considered as critical } \\
\text { success factors of SFM initiatives. } \\
\text { - Distribute information and communicate on sustainable practices. } \\
\text { - Merit and rewards for staff that promotes SFM. }\end{array}$ \\
\hline $\begin{array}{l}\text { Green Products } \\
\text { (Londoño \& Hernandez- } \\
\text { Maskivker, 2016; Yi, Li, \& Jai, } \\
\text { 2016) }\end{array}$ & $\begin{array}{l}\text { - Use green products to reduce negative environmental impacts. } \\
\text { - Many hotels have attempted to modify their existing products/services to be more } \\
\text { environmental friendly. }\end{array}$ \\
\hline $\begin{array}{l}\text { Community Collaboration } \\
\text { (Yi et al., 2016) }\end{array}$ & $\begin{array}{l}\text { - Study found that common practices implemented through boundless cooperation } \\
\text { of hotels and guests are preferring the recycling program (e.g. recycling waste) }\end{array}$ \\
\hline
\end{tabular}




\begin{tabular}{|c|c|}
\hline $\begin{array}{l}\text { Energy Management } \\
\text { (Bohdanowicz et al., 2011; } \\
\text { Elmualim et al., 2012; Horng, } \\
\text { Liu, Chou, Tsai, \& Chung, } \\
\text { 2017; Kuuder et al., 2013) }\end{array}$ & $\begin{array}{l}\text { - Innovation on energy-efficient appliances in hotels to reduce } \mathrm{CO}^{2} \text { emissions. For } \\
\text { example; energy-saving bulbs, non-single use of linens by the same guests, } \\
\text { reusable utensils. } \\
\text { - Train staff on environmental friendly awareness and practices. }\end{array}$ \\
\hline $\begin{array}{l}\text { Water Management } \\
\text { (Bohdanowicz, 2005; } \\
\text { Bohdanowicz et al., 2011; W. } \\
\text { W. Chan, 2005) }\end{array}$ & $\begin{array}{l}\text { - To date, hotel management team realized that water-saving practices are potential } \\
\text { in reduced operational cost. }\end{array}$ \\
\hline $\begin{array}{l}\text { Waste Management } \\
\text { (Mendes \& Santos, 2014; } \\
\text { Sadi \& Adebitan, 2014; Yi et } \\
\text { al., 2016) }\end{array}$ & $\begin{array}{l}\text { - Encouragement on using recyclable products in hotel rooms such as } \\
\text { biodegradable laundry plastics, ceramic mugs and refillable containers for } \\
\text { amenities products. } \\
\text { - Recycle bins with labels (glass, paper and plastics) in each guest rooms. } \\
\text { - Well managed of recyclable waste resulted in minimizing purchasing cost. }\end{array}$ \\
\hline $\begin{array}{l}\text { Air Quality Management } \\
\text { (Dixit et al., 2016; Järvensivu, } \\
\text { 2014) }\end{array}$ & $\begin{array}{l}\text { - Regular maintenance on air ventilator appliances and air conditioning systems } \\
\text { helps to improve indoor air quality. This is beneficial for the hotel management as } \\
\text { it reduces operational costs and increases business profits. }\end{array}$ \\
\hline $\begin{array}{l}\text { Noise Management } \\
\text { (Goldstein \& Primlani, 2012) }\end{array}$ & $\begin{array}{l}\text { - Noises from building equipments such as fans, boilers and compressors are } \\
\text { considered a nuisance to the hotel's staff and guests. Innovations and } \\
\text { improvements to reduce noises are in need and crucial for hotel management. }\end{array}$ \\
\hline
\end{tabular}

\subsection{Discussion}

Based on Table 4 above, many researchers focus on managing and coordination of human resources within the organization to achieve sustainable goals. According to ASEAN (2016), the SFM scope of human resource management in the hotel industry is to deliver the training programs for the operation and managing the employee for the sustainable program to achieve the corporate's sustainability goals. As mentioned by Chan \& Hsu (2016), the hotel organization play an essential role in coordinate human resource and organize a strategic plan for gaining sustainable advantages. Additionally, motivate staff encouragement on enhancing their commitment through merit and remuneration program by offering promotion opportunities, encouraging the atmosphere of partnership, and implementing other practices which as well to improve staffs wellbeing in the workplace.

On the other hand, recent evidence suggests that the hotel sector's contribution to global $\mathrm{CO}^{2}$ emissions is in the order of just $5 \%$ (in 2005), but might higher (from $5 \%$ to $14 \%$ ) if measured as radiative forcing, i.e. the warming caused by $\mathrm{CO}^{2}$ as well as other greenhouse gases (UNEP, (2008); UNWTO, (2008)). This calculation only includes energy throughout and does not add the energy needed to construct hotels, airports, highways, and runways (UNEP, 2008). Since then, many studies identified that many hotels had enhanced and improved by participating in energy conservation initiatives as part of performance measurement while reducing the $\mathrm{CO}^{2}$ emission (Nielsen et al., 2016). Besides, energy management is perceived to be an essential factor and the state-of-the-art of operating policies in hotels organisations (Mendes \& Santos, 2014). This means that reducing the energy requirements per unit of output is by strategically adjusting and optimizing energy on its systems and procedures while benefit also in reducing the total costs of producing the 
output from these systems (Vyas, Ahmed, \& Parashar, 2014). Moreover, the hotel's comprehensive water reduction efforts have shown considerable benefit. Many shreds of evidence have highlighted that improvements in water conservation also potential to recuperate operational cost (Bohdanowicz, 2005; Chan, 2005; Elmualim et al., 2009; Nielsen et al., 2016).

Water conservation can be done by aerated, reduced in pressure, and recycled as a means to reduce water waste. One of the most popular ways that hotels have reduced water consumption is replacing current appliances with water-efficient ones, including laundry facilities, toilets, showers, and faucets (Bruns-smith et al., 2015). For instance, one study showed that installing low-flow showerheads and aerated faucets saved $\$ 1.50$ per room per month for one hotel, and using water-efficient toilets kept the hotel 180,000 gallons of water per year (Bruns-smith et al., 2015; Cornell University, 2017). The volume of water used in a unit will depend on the water-saving potentials, which varies significantly at hotels depending on the type of facility and the occupancy rate of the hotel. Besides guest rooms and other ranges include landscape irrigation, office and staff areas, food service/preparation conference and banquet, special facilities, laundry and others (Cornell University, 2017). Therefore, these can be seen that there are numerous of efforts and effective ways for the implementation for water conservation, energy efficiency and waste reduction that can be done which evidently shown beneficial to both parties (i.e.hotels management and environment). Hence, the nine key SFM initiatives have shown that all the evidence of several studies has conducted SFM initiatives pertaining to the sustainability provision in the hotel industry.

\subsection{Conclusion}

The primary purpose of this study is to explore the SFM key initiatives for the hotel industry. The SFM practice in chronological development across the globe attained from the metaanalysis method on the SFM trends developing. Findings of this study indicate a total of 15 initiatives across the world, but only nine key initiatives of SFM are adopted by the hotel industry. The nine key initiatives identified are organisation policy, human resource, green products, community collaboration, energy management, water management, waste management, air quality management, and noise management. The implementation of these SFM initiatives are essential in the hotel industry to gain a successful holistic sustainable practice. SFM practice in the hotel often considers as the company's sustainability disclosures in their assessment of management quality and efficiency and reporting may provide the hotel better access to its capital. To recap, the benefits of SFM practice go beyond relating financial and opportunity of their performance enhancement but as well improvement of the hotel brands. Hence, this research sheds light on SFM practices which later intended to develop a framework of SFM in the hotel industry. 


\section{Acknowledgement}

The authors would like to acknowledge the contribution from the Institute of Research Management \& Innovation (IRMI) of University Teknologi MARA (UiTM) through supporting the research-:Geran Insentif Penyeliaan (GIP): 600-IRMI 5/3GIP (016/2019).

\section{References}

Alexander, K. (2009). European Facilities Management - The Next Generation. Retrieved from www.eurofm.org

Alonso-Almeida, M. del M., Fernández Robin, C., Celemín Pedroche, M. S., \& Astorga, P. S. (2017). Revisiting green practices in the hotel industry: A comparison between mature and emerging destinations. Journal of Cleaner Production, 140, 1415-1428. https://doi.org/10.1016/j.jclepro.2016.10.010

ASEAN Green Hotel Standard (AGHS). (2016). ASEAN Green Hotel Standard. ASEAN Tourism Standard Publication. Retrieved from http://www.asean.org/wp-content/uploads/2012/05/ASEAN-Green-Hotel-Standard.pdf

Baaki, T. K., Baharum, M. R., \& Ali, A. S. (2016). A review of sustainable facilities management knowledge and practice. MATEC Web of Conferences, 66, 1-10. https://doi.org/10.1051/matecconf/20166600075

Bohdanowicz, P. (2005). European hoteliers' environmental attitudes: Greening the business. Cornell Hotel and Restaurant Administration Quarterly, 46(2), 188-204. https://doi.org/10.1177/0010880404273891

Bohdanowicz, P., Zientara, P., \& Novotna, E. (2011). International hotel chains and environmental protection : an analysis of Hilton's we care ! programme (Europe , 2006 - 2008). Journal of Sustainable Tourism, 19, 37-41. https://doi.org/10.1080/09669582.2010.549566

Bowen, G. A. (2009). Document analysis as a qualitative research method. Qualitative Research Journal, 9(2), 2740. https://doi.org/10.3316/QRJ0902027

British Institute of Facilities Management (BIFM). (2018). EMBRACING WORKPLACE TO.

Brundtland International Institute for Sustainable Development. (2017). Sustainable Development | IISD. Retrieved April 19, 2017, from http://www.iisd.org/topic/sustainable-development

Bruns-smith, A., Choy, V., Chong, H., \& Verma, R. (2015). Environmental Sustainability in the Hospitality Industry : Best practices, Guest Participation, and Customer Satisfaction. Cornell Hospitality Report, Vol. 15, pp. 6-16. https://doi.org/10.1017/CBO9781107415324.004

Chan, E., \& Hsu, C. (2016). Environmental management research in hospitality. International Journal of Contemporary Hospitality Management, 28(5), 886-923. https://doi.org/10.1108/IJCHM-02-2015-0076

Chan, W. W. (2005). Partial analysis of the environmental costs generated by hotels in Hong Kong. International Journal of Hospitality Management, 24(4), 517-531. https://doi.org/10.1016/j.ijhm.2004.10.008

Chotipanich, S. (2006). Positioning Facility Management. Facilities, 22(13/14), 364-372. https://doi.org/10.1108/02632770410563086

Cornell University. (2017). Hotel Operations Management. Retrieved March 17, 2017, from https://www.sce.cornell.edu/sc/programs/index.php?v=172

Creswell, J. W. (2014). Research Design: Qualitative, Quantitative and Mixed Methods Approaches (Fourth). 58 
California: Sage Publications, Inc.

Dixit, M. K., Culp, C. H., Fernandez-Solis, J. L., \& Lavy, S. (2016). Reducing carbon footprint of facilities using a facility management approach. Facilities, 34(3/4), 247-259. https://doi.org/10.1108/F-11-2014-0091

Durodola, O. D., Abiodun Ayedun, C., \& Omolade Adedoyin, A. (2012). Beneficial application of facilities management in hotel organizations in south-western Nigeria. Mediterranean Journal of Social Sciences, 3(1), 413 423. https://doi.org/10.5901/mjss.2012.03.01.413

EarthCheck. (2018). Company Standard (pp. 1-15). pp. 1-15. Retrieved from www.earthcheck.org

Elmualim, A., Valle, R., \& Kwawu, W. (2012). Discerning policy and drivers for sustainable facilities management practice. International Journal of Sustainable Built Environment, 1(1), 16-25. https://doi.org/10.1016/j.ijsbe.2012.03.001

Elmualim, A., Valle, R., Pastou, M., \& Ludlow, G. (2009). Innovation in Sustainable Facilities Management Practice : Implementing a Sustainability Policy. Facilities Management, 176-185.

EMS. (2008). Environmental Management Systems (EMS). International Institute for Environment and Development (IIED), Vol. 198, pp. 27-28.

Environmental Protection Agency (EPA). (2013). Resource Efficiency in the Hospitality Sector.

Ernst and Young. (2013). 2013 Six Growing Trends in Corporate Sustainability.

Fotiadis, A. K., Vassiliadis, C. A., \& Rekleitis, P. D. (2013). Constraints and benefits of sustainable development: A case study based on the perceptions of small-hotel entrepreneurs in Greece. Anatolia, 24(2), 144-161. https://doi.org/10.1080/13032917.2012.741049

Global Sustainable Tourism Council (GSTC). (2013). Global Sustainable Tourism Council Criteria Hotels and Tour Operators (pp. 1-11). pp. 1-11. Retrieved from http://www.gstcouncil.org/sustainable-tourism-gstc-criteria/criteriafor-hotels-and-tour-operators.html

Göğüş, G., Karakadılar, İ. S., \& Apak, S. (2013). Innovation and Sustainable Growth Measurement in Hotel Industry: A Hierarchical Decision Making Model. Procedia - Social and Behavioral Sciences, 99, 752-761. https://doi.org/10.1016/j.sbspro.2013.10.547

Goldstein, K., \& Primlani, R. V. (2012). Current trends and opportunities in hotel sustainability. In HVS Sustainability Services. Retrieved from http://www.hvs.com/article/5655/current-trends-and-opportunities-in-hotel-sustainability/

Green Globe. (2014). The Premier Global Certification for Sustainability Hotel. Retrieved from greenglobe.com

Green Key Global. (2010). Green Key Global \& the Programs (pp. 1-3). pp. 1-3. Retrieved from www.greenkeyglobal.com

Green Seal. (2018). Green Seal Standard for Hotels and Lodging Properties (Vol. 5525, pp. 1-26). Vol. 5525, pp. 1-26. Retrieved from greenseal.org

Hasim, M. S., Pullen, S., \& Sivam, A. (2012). Sustainability Practices in Organizations : Comparative Analysis Between Australia and Malaysia on. (December), 4-5.

Hodges, C. P. (2014). Sustainable Facility Management - The Integration of Sustainability into a Facility Manager's Core Competencies. 
Horng, J.-S., Liu, C.-H., Chou, S.-F., Tsai, C.-Y., \& Chung, Y.-C. (2017). From innovation to sustainability: Sustainability innovations of eco-friendly hotels in Taiwan. International Journal of Hospitality Management, 63, 4452. https://doi.org/10.1016/j.ijhm.2017.02.005

International Facility Management Association (IFMA). (2018). A Sustainable Framework. Retrieved October 29, 2019, from IFMA Knowledge Library website: http://community.ifma.org/knowledge_library

Iwanowski, K., \& Rushmore, C. (1994). Introducing the Eco-Friendly Hotel. Cornell Hotel and Restaurant Administration Quarterly, 35(1), 34-38. https://doi.org/10.1177/001088049403500104

Järvensivu, J. (2014). Environmental Sustainability in Hotel Facilities A Case Study: Original Sokos Hotel Villa. (May). Retrieved from https://www.theseus.fi/bitstream/handle/10024/79162/Jarvensivu_Jenny.pdf?sequence=1

Jayawardena, C. (Chandi), Pollard, A., Chort, V., Choi, C., \& Kibicho, W. (2013). Trends and sustainability in the Canadian tourism and hospitality industry. Worldwide Hospitality and Tourism Themes, 5(2), 132-150. https://doi.org/10.1108/17554211311314164

Jenkins, N. R., \& Karanikola, I. (2014). Do hotel companies communicate their environmental policies and practices more than independent hotels in Dubai, UAE? Worldwide Hospitality and Tourism Themes, 6(4), 362. https://doi.org/10.1108/WHATT-01-2014-0003

Junghans, A. (2011). State of the Art in Sustainable Facility Management. 5th Nordic Conference on Construction Economics and Organisation, 553-564.

Junghans, A., \& O.E. Olsson, N. (2014). Discussion of facilities management as an academic discipline. Facilities, 32(1/2), 67-79. https://doi.org/10.1108/F-10-2012-0078

Kutanis, R. O., Mesci, M., Comlekci, I., \& Sahin, O. (2012). Investigating Hotel Employee Involvement in Strategic Human Resources Management. Journal of Tourism, 7(1), 117-134.

Kuuder, C. W., Bagson, E., Prempeh, V. M., Mumuni, A., Adongo, R., \& Amoako, E. E. (2013). Energy , Water and Waste Management in the Accommodation Sector of Tamale Metropolis, Ghana. American Journal of Tourism Mnagement, 2, 1-9. https://doi.org/10.5923/s.tourism.201304.01

Lai, J. H. K., \& Choi, E. C. K. (2015). Performance measurement for teaching hotels: A hierarchical system incorporating facilities management. Journal of Hospitality, Leisure, Sport and Tourism Education, 16, 48-58. https://doi.org/10.1016/j.jhlste.2015.02.002

LEED. (2013). Practical Strategies in Green Building: Hotels (p. 20). p. 20. Retrieved from http://www.usgbc.org/resources/practical-strategies-green-building-hotels

Londoño, M. P. L., \& Hernandez-Maskivker, G. (2016). Green practices in hotels: the case of the GreenLeaders Program from TripAdvisor. 201(St), 1-13. https://doi.org/10.2495/ST160011

Malaysia National Ecotourism Plan (MNEP). (2016). Malaysia National Ecotourism Plan 2016-2025. Ministry of Tourism and Culture Malaysia, Vol. 39, pp. 561-563. Retrieved from http://www.comcec.org/en/wpcontent/uploads/2019/02/6.4.Malasia_NEP-COMCEC.pdf

Melissen, F., van Ginneken, R., \& Wood, R. C. (2016). Sustainability challenges and opportunities arising from the owner-operator split in hotels. International Journal of Hospitality Management, 54, 35-42. https://doi.org/10.1016/j.ijhm.2016.01.005 
Abu Talib, A.A., et.al. / Asian Journal of Quality of Life (AjQoL), 4(17) Sep / Dec 2019 (p.49-62)

Mendes, J. P., \& Santos, S. (2014). Energy Management in Four and Five Star Hotels in Algarve (Portugal). Turizam International Scientific Journal, 18(3), 95-112. Retrieved from http://www.dgt.uns.ac.rs/turizam/arhiva/vol_1803_1.pdf

Meng, X. (2015). Facilities Management: Tracing Its Development Trajectory. Property Management, 33(3), 212 223. https://doi.org/10.1108/PM-12-2013-0059

Nazeer, F. S., Gunatilake, S., \& Ramachandra, T. (2019). Significant Sustainable Facilities Management (SFM) Practices in the Health Care (HC) Sector. IOP Conference Series: Earth and Environmental Science, 290(1). https://doi.org/10.1088/1755-1315/290/1/012055

Neuman, W. L. (2014). Social Research Methods: Qualitative and Quantitative Approaches. In Teaching Sociology (7th editio, Vol. 30). https://doi.org/10.2307/3211488

Nielsen, S. B., \& Galamba, K. R. (2010). Facilities Management - when Sustainable Development is Core Business. EuroFM Research Symposium, 1-19.

Nielsen, S. B., Sarasoja, A.-L., \& Galamba, K. R. (2016). Sustainability in Facilities Management: an Overview of Current Research. Facilities, 34(9/10), 535-563. https://doi.org/10.1108//JCHM-09-2013-0421

Penny, W. Y. K. (2007). The use of environmental management as a facilities management tool in the Macao hotel sector. Emerald Insight: Facilities, 25(7/8), 286-295. https://doi.org/10.1108/02632770710753325

Razumova, M., Rey-Maquieira, J., \& Lozano, J. (2016). The role of water tariffs as a determinant of water saving innovations in the hotel sector. International Journal of Hospitality Management, 52, 78-86. https://doi.org/10.1016/j.ijhm.2015.09.011

Sadi, I. A., \& Adebitan, E. O. (2014). Waste Water Recycling in the Hospitality Industry. Academic Journal of Interdisciplinary Studies, 3(7), 87-95. https://doi.org/10.5901/ajis.2014.v3n7p87

Singapore Tourism Board (STB). (2015). Sustainable Growth for Singapore's Hotel Industry. Singapore Tourism Board. Retrieved from stb_hotels@stb.gov.sg.

United Nation Environmental Protection (UNEP). (2017). Regional Study on Mercury: Waste Management in ASEAN region.

United Nations Environment Program (UNEP). (2008). Adaptation and Mitigation in the Tourism Sector: Frameworks, Tools and Practices. https://doi.org/978-92-807-2921-5

United Nations World Tourism Organization (UNWTO). (2008). Climate Change and Tourism Responding to Global Challenges. In United Nations Organization World Tourism, UNWTO. https://doi.org/10.1007/978-3-7908-1718-8

UNWTO. (2018). UNWTO Tourism Highlights. International Tourism Trends 2017. https://doi.org/https://doi.org/10.18111/9789284419876

Vyas, D. S., Ahmed, A. S., \& Parashar, A. A. (2014). BEE (Bureau of Energy Efficiency) and GREEN BUILDINGS. International Journal of Research, 1(3), 23-32.

Yi, S., Li, X., \& Jai, T. C. (2016). Hotel guests ' perception of best green practices : A content analysis of online reviews. Tourism and Hospitality Research, 1-12. https://doi.org/10.1177/1467358416637251

Yusof, Z. B., \& Jamaludin, M. (2013). Green Approaches of Malaysian Green Hotels and Resorts. Procedia - Social and Behavioral Sciences, 85(0), 421-431. https://doi.org/http://dx.doi.org/10.1016/j.sbspro.2014.10.083 
Abu Talib, A.A., et.al. / Asian Journal of Quality of Life (AjQoL), 4(17) Sep / Dec 2019 (p.49-62)

Zaiton, S., Herman, S., Kasimu, A. B., \& Hassan, H. (2016). Sustainable Tourism Practices Among Hotels in Malaysia: Financial and Non-Financial Benefits. Journal of Sustainability Science and Management, 11(1), 73-81. 